\title{
Novel adhesive system based on 1,3-dimethylol-4,5- dihydroxyethyleneurea (DMDHEU) and hyperbranched polyglycerols
}

\author{
Mariusz L. Mamiński · Sylwia Witek • \\ Karolina Szymona $\cdot$ Paweł Parzuchowski
}

Received: 12 October 2012/Published online: 10 February 2013

(C) The Author(s) 2013. This article is published with open access at Springerlink.com

\begin{abstract}
Two hyperbranched polyglycerols bearing 1,1,1-tris(hydroxymethyl)propane or Bisphenol A core and terminal hydroxyl functionality were examined as components of novel wood adhesive systems. Two 1,3-dimethylol-4,5-dihydroxyethyleneurea resins (DMDHEU) were used as crosslinkers. Shear strength tests revealed that the adhesives containing up to $75 \mathrm{wt} \%$ of renewable glycerolderived polyglycerols retained performance comparable to that of neat DMDHEU. The results give way to extending the area of application of hyperbranched polyglycerols in the field of wood adhesives.
\end{abstract}

Neues Klebstoffsystem auf Basis von 1,3-dimethylol-4,5dihydroxyethyleneurea (DMDHEU) und hyperverzweigten Polyglycerinen

Zusammenfassung Zwei hyperverzweigte Polyglycerine (HBPGs) mit einem 1,1,1-Tris(hydroxymethyl)propan oder einem Bisphenol A Kern und einer endständigen Hydroxygruppe wurden als Komponenten eines neuen Holzklebstoffsystems untersucht. Zwei 1,3-dimethylol-4,5dihydroxyethyleneurea Harze (DMDHEU) wurden zur Vernetzung verwendet. Scherfestigkeitsprüfungen zeigten, dass Klebstoffe, die erneuerbare aus Glycerinen hergestellte Polyglycerine mit bis zu $75 \%$ Masseanteil enthielten, ähnliche Eigenschaften wie pures DMDHEU

M. Ł. Mamiński $(\bowtie) \cdot$ S. Witek · K. Szymona

Faculty of Wood Technology, Warsaw University of Life

Sciences-SGGW, 159 Nowoursynowska St.,

02-776 Warsaw, Poland

e-mail: mariusz_maminski@sggw.pl

P. Parzuchowski

Faculty of Chemistry, Warsaw University of Technology,

3 Noakowskiego St., 00-664 Warsaw, Poland aufwiesen. Die Ergebnisse legen den Grundstock, um das Anwendungsgebiet von hyperverzweigten Polyglycerinen auf Holzklebstoffe auszudehnen.

\section{Introduction}

One of the twelve principles of green chemistry states that "synthetic methods should be designed to use and generate substances that possess little or no toxicity to human health and the environment" (Anastas and Warner 1998). Simultaneously, in 2004 the International Agency for Research on Cancer (IARC 2004) classified formaldehyde as "cancerogenic to humans" which stimulated research in three main directions: (1) formaldehyde-free adhesives (Mansouri et al. 2007, Ballerini et al. 2005; Liu and Li 2007), (2) adhesive systems of low formaldehyde content (US Patent 2011) or (3) formaldehyde replacing by other aldehydes (Mamiński et al. 2011a; Mansouri and Pizzi 2006; Wang and Pizzi 1997).

On the other hand, fluctuation of oil prices and environmental policies have been stimulating factors for the development of technologies based on renewable resources for a long time, so that the significance of carbohydrates, oils, lignins, tannins or proteins has increased (García and Pizzi 1998; Li et al. 2004; Çetin and Özman 2002).

Growing biodiesel production and saponification of fats and oils generate substantial surplus of crude glycerol (1,2,3-trihydroxypropane) (Bournay et al. 2005; Ramadhas et al. 2005; Behr et al. 2008). In 2009 the supply of glycerol reached 900 thousand tons (Melero et al. 2012), while 1.2 million tons is estimated in 2012 (Zhou et al. 2008). Thus, it is apparent that such supply of raw material cannot be neglected therefore new utilization areas for glycerol are being researched. 
Commonly recognized fields of glycerol consumption are pharmaceuticals, cosmetics or alkyd resins. On the other hand, there are some more sophisticated transformations of glycerol to valuable raw materials: bioconversion to citric acid (Papanikolau et al. 2002), dimethyl carbonate (Kim et al. 2007), catalytic conversion to hydrogen fuel (Sánchez et al. 2010) or propanediol (Alhanash et al. 2008). Rokicki et al. (2005) reported a convenient transformation of glycerol to cyclic glycerol carbonate and further to hyperbranched polyglycerols. Previous works by the authors showed the applicability of hyperbranched polyglycerols in the formulation of polyurethane (Mamiński et al. 2011b) or polyglycerol-melamine-formaldehyde (Mamiński et al. 2011c) adhesive systems.

In the literature, there are numerous reports on 1,3dimethylol-4,5-dihydroxyethyleneurea (DMDHEU) which seem useful in wood bonding technology. However, original use of DMDHEU is textile industry. Although, it was successfully transferred to wood technology, so that there are reports on wood or veneer modifications (Militz 1993; Sudiyanni et al. 1996; Krause et al. 2003; Wepner et al. 2006; Schaffert et al. 2005; Dieste et al. 2009), no reports on DMDHEU-based adhesive systems are available.

Since DMDHEU has four hydroxyl groups: two $\mathrm{N}$-methylol and two secondary hydroxyls that are able to react with the hydroxyl groups of another compound (Yang et al. 2009; Ibrahim et al. 2008), it was assumed that DMDHEU-crosslinked polyglycerols would possibly work as adhesives for wood bonding.

Therefore, this paper contains the results of investigations on the performance of novel adhesive systems based on dimethyloldihydroxyethyleneurea (DMDHEU) and hyperbranched polyglycerols (HBPGs). The effect of hyperbranched polyglycerol structure on dry and wet shear strengths of lap joints made in solid wood is described.

\section{Materials and methods}

All chemicals were purchased from Sigma-Aldrich and used as obtained. An unmodified DMDHEU resin (unDMDHEU) (pH 6.0; solids $83 \%$; viscosity $550 \mathrm{mPas}$ ) was kindly donated by Omnova Solutions Inc. (UK). A modified 1,3-dimethylol-4,5-dihydroxyethyleneurea (mDMD-

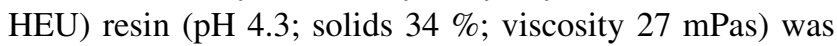
kindly donated by BASF Chemicals (Germany).

Viscosities were measured at $20{ }^{\circ} \mathrm{C}$ on a Brookfield DV $\mathrm{II}+$ Pro viscometer equipped with a spindle no. 64. FTIR spectra were recorded on Bio-Rad FTS165 instrument. Each spectrum was taken as an average of 32 scans at a resolution of $4 \mathrm{~cm}^{-1}$. Size Exclusion Chromatography (SEC) measurements were made on GPC LabAlliance apparatus with a Jordi Gel DVB Mixed Bed $(250 \mathrm{~mm} \times 10 \mathrm{~mm})$ column using water eluent (1) or DMF (2) as an eluent at $35^{\circ} \mathrm{C}$ and poly(ethylene oxide) or polystyrene for the calibration. ${ }^{1} \mathrm{H}$ NMR spectra were recorded on a Varian VXR $400 \mathrm{MHz}$ NMR spectrometer.

MALDI-TOF spectroscopy The postulated structures of $\mathbf{1}$ and $\mathbf{2}$ were confirmed by MALDI-TOF experiments (Figs. 1, 2). MALDI-TOF spectra were measured on a Bruker UltraFlex (Bremen, Germany) spectrometer using DHB (2,5-dihydroxybenzoic acid) or Dithranol (1,8-dihydroxyanthrone) as a matrix.

\subsection{Hyperbranched polyglycerol synthesis}

Hyperbranched polyglycerol 1 was synthesized from (1,1,1trishydroxymethylpropane) as the core of molecule and glycerol carbonate (GC) as branching monomer. In a $0.5 \mathrm{~L}$ 3 -neck flask equipped with a magnetic stirrer, thermometer, dropping funnel and a bubble meter TMP $(22.8 \mathrm{~g}, 0.17 \mathrm{~mol})$ was placed followed by $0.28 \mathrm{~g}(2 \mathrm{mmol})$ of potassium carbonate. The reaction mixture was heated at $160{ }^{\circ} \mathrm{C}$. Glycerol carbonate $(200 \mathrm{~g}, 1.69 \mathrm{~mol})$ was added drop wise during $17 \mathrm{~h}$ at $160{ }^{\circ} \mathrm{C}$. Then the reaction mixture was heated for additional $8 \mathrm{~h}$ until a characteristic cyclic carbonate band at $1786 \mathrm{~cm}^{-1}$ disappeared completely in the FTIR spectrum. The crude product was obtained as a viscous dark yellow liquid. It was dissolved in $500 \mathrm{~mL}$ of water and potassium carbonate was neutralized with $\mathrm{HCl}$. Water was removed under reduced pressure. The polymer was dried at $100{ }^{\circ} \mathrm{C}(0.05$ Tor $)$ for $6 \mathrm{~h}$. Dark yellow oil of viscosity $9.5 \mathrm{~Pa} \cdot \mathrm{s}$ at $20{ }^{\circ} \mathrm{C}$ was obtained. Yield was $141.3 \mathrm{~g}(95 \%)$. Hydroxyl functionality was 13 based on ${ }^{1} \mathrm{H}$ NMR.

${ }^{1} \mathrm{H}$ NMR (400 MHz, $\left.\mathrm{D}_{2} \mathrm{O}\right), \delta(\mathrm{ppm}): 4.79\left(\mathrm{H}_{2} \mathrm{O}, \mathrm{OH}\right)$, 4.12-3.07 (m, 56H, polyether backbone), 1.38 (bs, $2 \mathrm{H}$, $\mathrm{CH}_{2} \mathrm{CH}_{3}$ ), 0.93 (bs, $3 \mathrm{H}, \mathrm{CH}_{2} \mathrm{CH}_{3}$ ); FT-IR (KBr); $\mathrm{cm}^{-1}=$ $3,380,2,870,1,070 ;$ SEC: $\mathrm{M}_{\mathrm{n}}=736, \mathrm{M}_{\mathrm{w}}=1,268, \mathrm{D}=1.72$

Hyperbranched polyglycerol 2 was synthesized from bisphenol $\mathrm{A}$ as the core molecule and glycerol carbonate (GC) used in 1:5 molar ratio. In a 3-neck reactor equipped with magnetic stirrer, condenser and dripping funnel, $5.70 \mathrm{~g}(25 \mathrm{mmol})$ bisphenol $\mathrm{A}$ and $0.042 \mathrm{~g}(0.75 \mathrm{mmol})$ potassium hydroxide were molten at $170{ }^{\circ} \mathrm{C}$ and then $14.76 \mathrm{~g}$ (125 mmol) glycerol carbonate was added drop wise for $20 \mathrm{~h}$. The reaction was performed until depletion of glycerol carbonate. FT-IR $(\mathrm{KBr}) ; \mathrm{cm}^{-1}=3,368,2,879$, 1,042, 830, 574. SEC: $M_{n}=450, M_{w}=714, D=1.56$. ${ }^{1} \mathrm{H}$ NMR spectrum is shown in Fig. 3.

\subsection{Adhesive formulation and gel time}

A portion of DMDHEU resin (mDMDHEU or unDMDHEU) and polyglycerol $\mathbf{1}$ or $\mathbf{2}$ were weighted on an aluminium pan, 
Fig. 1 MALDI-TOF spectrum of hyperbranched polyglycerol $\mathbf{1}$ and exemplary repeating peak sequence

Abb. 1 MALDI-TOF Spektrum des hyperverzweigten

Polyglycerins 1 und Beispiel einer sich wiederholenden PeakSequenz

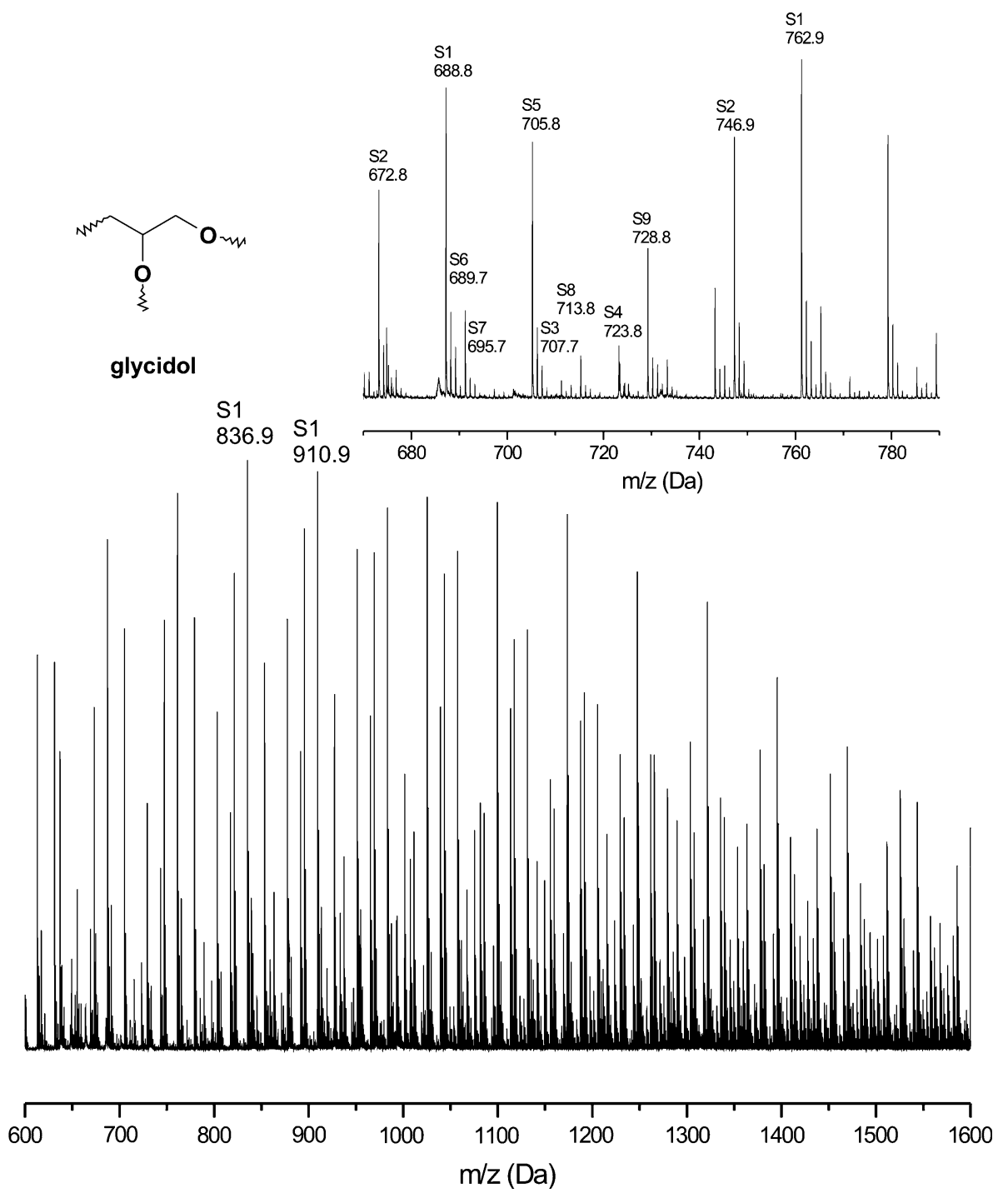

so that a preset weight ratio based on solids was achieved. Then the components were mixed thoroughly and the catalyst (p-toluenesulfonic acid or magnesium chloride) was added ( $5 \mathrm{wt} \%$ based on solids). After complete dissolving of the catalyst, the adhesive was applied onto the beech specimens $\left(120 \mathrm{~g} / \mathrm{m}^{2}, 700 \pm 45 \mathrm{~kg} / \mathrm{m}^{3}, 5.3 \%\right.$ moisture content $)$ prepared according to EN 205 (2005).

Gel time of the adhesive systems was determined according to the following procedure: approximately $1.0 \mathrm{~g}$ portion of the mixture was placed on an aluminium pan (70 $\mathrm{mm}$ diameter) and heated at $170{ }^{\circ} \mathrm{C}$ until gellation.

\subsection{Lap joints bonding}

Bonding was performed in a hot press $\left(170{ }^{\circ} \mathrm{C}\right)$ under pressure of 1.2 MPa for $8 \mathrm{~min}$. The bonded samples were conditioned at $20 \pm 2{ }^{\circ} \mathrm{C}$ and $65 \pm 5 \%$ relative humidity for 7 days. Pressing time and platen temperature were not subject of optimization in these investigations.

\subsection{Shear strength of the joints}

Test samples $\left(150 \times 20 \times 5 \mathrm{~mm}^{3}\right)$ of the lap area ca. $200 \mathrm{~mm}^{2}$ were subjected to shear strength tests. The reference samples were bonded with neat mDMDHEU or unDMDHEU resin cured with p-TSA or $\mathrm{MgCl}_{2}$ under alike bonding conditions. Wet shear strength tests were performed on the specimens subjected to $24 \mathrm{~h}$ water soaking. Twenty samples were tested in each series.

\subsection{Activation energy}

Determination of activation energy for the DMDHEUpolyglycerol systems was derived from gel time measured at 150,170 and $190{ }^{\circ} \mathrm{C}$. Calculations were based on Arrhenius Eq. (1) as follows:

$\ln k=\ln A-\frac{E_{a}}{R T}$ 
Fig. 2 MALDI TOF spectrum of hyperbranched polyglycerol 2 and exemplary repeating peak sequence

Abb. 2 MALDI-TOF Spektrum des hyperverzweigten

Polyglycerins 2 und Beispiel einer sich wiederholenden PeakSequenz

Fig. $3{ }^{1} \mathrm{H}$ NMR $(400 \mathrm{MHz}-$ DMSO-d $\mathrm{d}_{6}$ ) spectrum of hyperbranched polyglycerol 2 Abb. $3{ }^{1} \mathrm{H}$ NMR (400 MHzDMSO-d6) Spektrum von hyperverzweigtem Polyglycerin 2
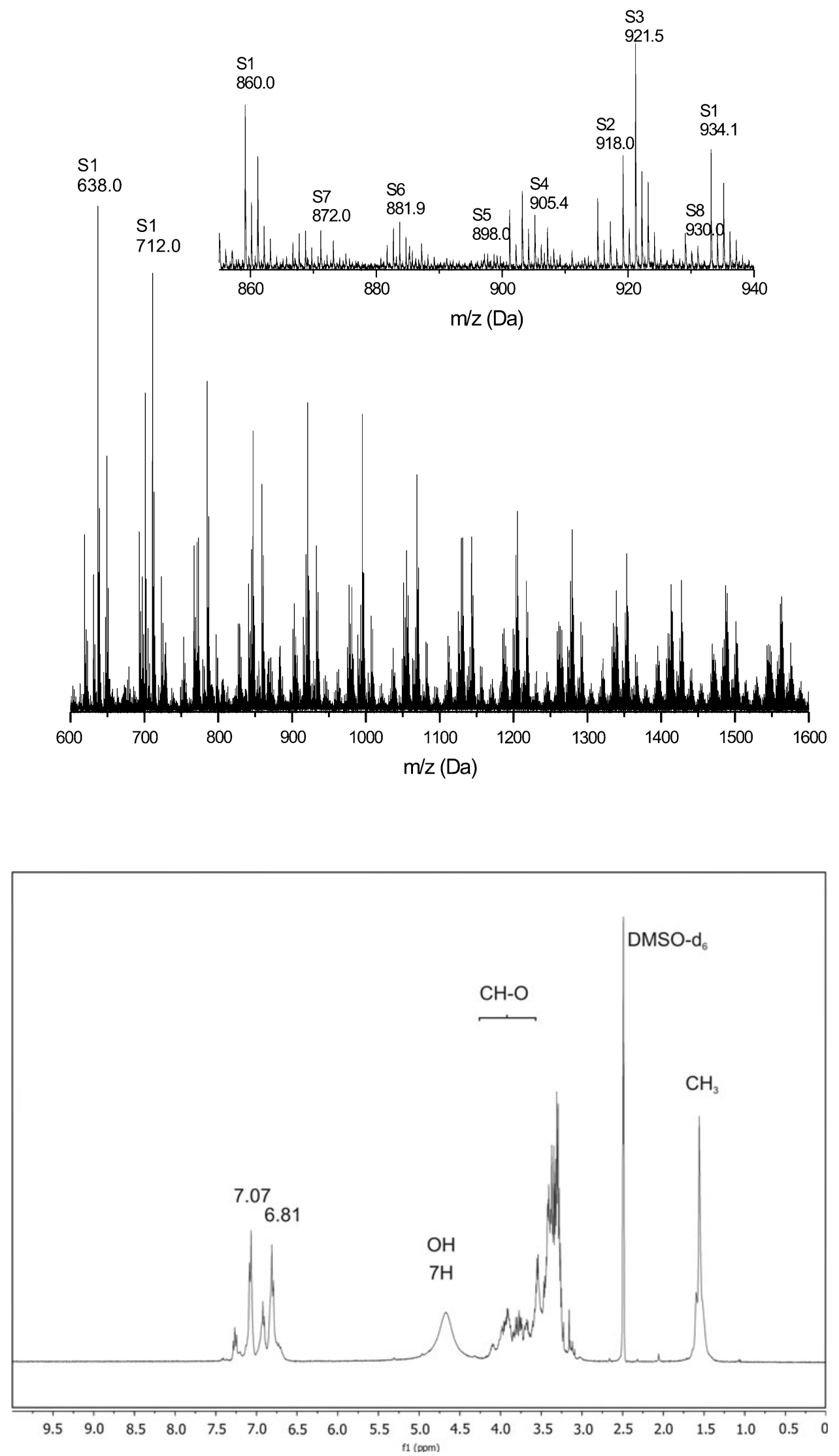
where $k$ is reaction rate constant, $A$ is prexpotential factor, $E_{a}$ is the activation energy, $R$ is gas constant (8.314 $\left.\mathrm{J} \cdot \mathrm{mol}^{-1} \mathrm{~K}\right), T$ is temperature.

\section{Results and discussion}

\subsection{Polyglycerol structure}

On the contrary to dendrimers that require multi-step approach involving tedious purification after each step, hyperbranched polyglycerols are synthesised in 'one-pot' synthesis which results in their substantial polydispersity (Galina and Krawczyk 2007; Fradét and Tessier 2006). For better description of molecular structures of the studied polyglycerols, their polydispersity as well as incorporation of the core molecule into the structure were investigated by means of MALDI-TOF spectrometry.

The spectrum shown in Fig. 1 revealed, apart from the properly developed HBPG 1 molecules with TMP core, both no-core and cyclic structures. Since glycidol is a repeating unit, the $m / z$ distance between peaks in the sequence is 74. The assignments of the corresponding peaks are shown in Table 1. Peaks S1 and S2 come from molecules bearing 1 TMP core and $n$ repeating glycidol units. Peaks S3 and S4 indicate molecules containing 1 glycerol core and $n$ glycidol units. Cyclic structures built solely of glycidol units were also found (peaks S5 and S6). Peaks S7 and S8 were assigned to the structures formed upon the analysis by attachment of glycidol units to DHB, while S9 peak was assigned to cyclic structure containing 1 TMP core and $n$ glycidol units. However, the dominating molecular structure was that assigned to $\mathrm{S} 1$ peak at $\mathrm{m} / \mathrm{z}$ 836.9 and 910.9 Da-i.e. 1 TMP and 9 or 10 glycidol units, respectively.

MALDI-TOF spectra for polyglycerol 2 shown in Fig. 2 indicate the presence of molecules of the designed

Table 1 Assignments of the peaks from MALDI-TOF spectrum of 1 Tab. 1 Zuordnungen der Peaks aus dem MALDI-TOF Spektrum von 1

\begin{tabular}{lllll}
\hline Peak & Alpha end group (core) & Repeating unit & Adduct & Loss \\
\hline S1 & TMP & Glycidol & $\mathrm{K}$ & - \\
S2 & TMP & Glycidol & $\mathrm{Na}$ & - \\
S3 & Glycerol & Glycidol & $\mathrm{Na}$ & - \\
S4 & Glycerol & Glycidol & $\mathrm{K}$ & - \\
S5 & - & Glycidol & $\mathrm{K}$ & - \\
S6 & - & Glycidol & $\mathrm{Na}$ & - \\
S7 & DHB & Glycidol & $\mathrm{Na}$ & - \\
S8 & DHB & Glycidol & $\mathrm{K}$ & - \\
S9 & TMP & Glycidol & $\mathrm{K}$ & $\mathrm{H}_{2} \mathrm{O}$ \\
\hline
\end{tabular}

Table 2 Assignments of the peaks from MALDI-TOF spectrum of 2 Tab. 2 Zuordnungen der Peaks aus dem MALDI-TOF Spektrum von 2

\begin{tabular}{lllll}
\hline Peak & Alpha end group (core) & Repeating unit & Adduct & Loss \\
\hline S1 & Bisphenol A & Glycidol & $\mathrm{K}$ & - \\
S2 & Bisphenol A & Glycidol & $\mathrm{Na}$ & - \\
S3 & Bisphenol A dimer & Glycidol & $\mathrm{K}$ & - \\
S4 & Bisphenol A dimer & Glycidol & $\mathrm{Na}$ & - \\
S5 & Glycerol carbonate & Glycidol & $\mathrm{K}$ & - \\
S6 & Glycerol carbonate & Glycidol & $\mathrm{Na}$ & - \\
S7 & Glycerol & Glycidol & $\mathrm{K}$ & - \\
S8 & Glycerol & Glycidol & $\mathrm{Na}$ & - \\
\hline
\end{tabular}

structure-1 bisphenol A core and $n$ glycidol units (peaks $\mathrm{S} 1$ and S2). What is more interesting, both molecules bearing bisphenol A dimer (S3 and S4) or glycerol carbonate (S5 and S6) or glycerol (S7 and S8) in the core were also found, but, unlike polyglycerol $\mathbf{1}$, no cyclic structures were indicated (Table 2). The dominating structures were those having 1 bisphenol A core and 5 or 6 glycidol units (S1 at $m / z, 638.0$ and 712.0 Da in Fig. 2).

NMR spectrum of polyglycerol 2 shown in Fig. 3 proved that branched structures had been built from both hydroxyls of bisphenol A. No phenolic $\mathrm{OH}$ protons at $9.16 \mathrm{ppm}$ can be observed. Moreover, found chemical shifts of the aromatic protons were 7.07 and 6.81 instead of typical 6.98 and $6.64 \mathrm{ppm}$ (SDBSWeb) confirming the presence of disubstituted bisphenol A core.

\subsection{Performance of the adhesives}

Characteristics of the adhesive formulations used in the bonding experiments are shown in Table 3. Reactivity of unDMDHEU resin was lower than that of mDMDHEU, so that a temperature of $170{ }^{\circ} \mathrm{C}$ was necessary for achieving gel point in a reasonable amount of time-i.e. 120-480 s, while mDMDHEU-series were curable at $100{ }^{\circ} \mathrm{C}$. At $100{ }^{\circ} \mathrm{C}$ no gellation for unDMDHEU resin occurred, therefore temperature was increased to $170{ }^{\circ} \mathrm{C}$. In that case, magnesium chloride was found more effective as a catalyst. Regardless of the polyglycerol used, the mixtures with mDMDHEU resin and p-TSA exhibited significantly shorter gel times. However, for the mDMDHEU-polyglycerol $1: 3$, w/w systems at $100{ }^{\circ} \mathrm{C}$ no gellation was achieved. Thus, bonding was performed at $170{ }^{\circ} \mathrm{C}$ which, as reported in literature, is a typical curing temperature for DMDHEU resins (Dieste et al. 2009, Yang et al. 2009).

High viscosity of neat polyglycerol 2 resulted in significant increase in the viscosities of the studied mixtures that exceeded $500 \mathrm{~Pa} \cdot \mathrm{s}$ at 3:1 w/w components' ratio. Pot lives of all the formulations were longer than $12 \mathrm{~h}$ which is 
Table 3 Characteristics of the studied adhesive formulations

Tab. 3 Eigenschaften der untersuchten Klebstoffrezepturen

\begin{tabular}{|c|c|c|c|c|c|c|c|}
\hline HBPG & DMDHEU & Weight ratio & Catalyst & Viscosity at $20^{\circ} \mathrm{C}(\mathrm{Pa} \cdot \mathrm{s})$ & Gel time at $170{ }^{\circ} \mathrm{C}(\mathrm{s})$ & Pot life (h) & $\mathrm{E}_{\mathrm{a}}(\mathrm{kJ} / \mathrm{mol})$ \\
\hline- & mDMDHEU & - & TSA & - & 35 & $>12$ & 55.1 \\
\hline- & unDMDHEU & - & $\mathrm{MgCl}_{2}$ & - & 120 & $>12$ & 50.0 \\
\hline 1 & mDMDHEU & $1: 1$ & TSA & 1.3 & 90 & $>12$ & - \\
\hline 1 & mDMDHEU & $2: 1$ & TSA & 3.1 & 90 & $>12$ & 67.9 \\
\hline 1 & mDMDHEU & $3: 1$ & TSA & 5.4 & 130 & $>12$ & - \\
\hline 1 & unDMDHEU & $1: 1$ & $\mathrm{MgCl}_{2}$ & 5.1 & 120 & $>12$ & 56.0 \\
\hline 1 & unDMDHEU & $2: 1$ & $\mathrm{MgCl}_{2}$ & 7.5 & 300 & $>12$ & - \\
\hline 1 & unDMDHEU & $3: 1$ & $\mathrm{MgCl}_{2}$ & 8.8 & 480 & $>12$ & - \\
\hline 2 & mDMDHEU & $1: 1$ & TSA & 7.2 & 80 & $>12$ & - \\
\hline 2 & mDMDHEU & $2: 1$ & TSA & 19.6 & 90 & $>12$ & 73.1 \\
\hline 2 & mDMDHEU & $3: 1$ & TSA & 38.4 & 140 & $>12$ & - \\
\hline 2 & unDMDHEU & $1: 1$ & $\mathrm{MgCl}_{2}$ & 205 & 80 & $>12$ & - \\
\hline 2 & unDMDHEU & $2: 1$ & $\mathrm{MgCl}_{2}$ & 436 & 80 & $>12$ & 82.3 \\
\hline 2 & unDMDHEU & $3: 1$ & $\mathrm{MgCl}_{2}$ & 550 & 150 & $>12$ & - \\
\hline
\end{tabular}

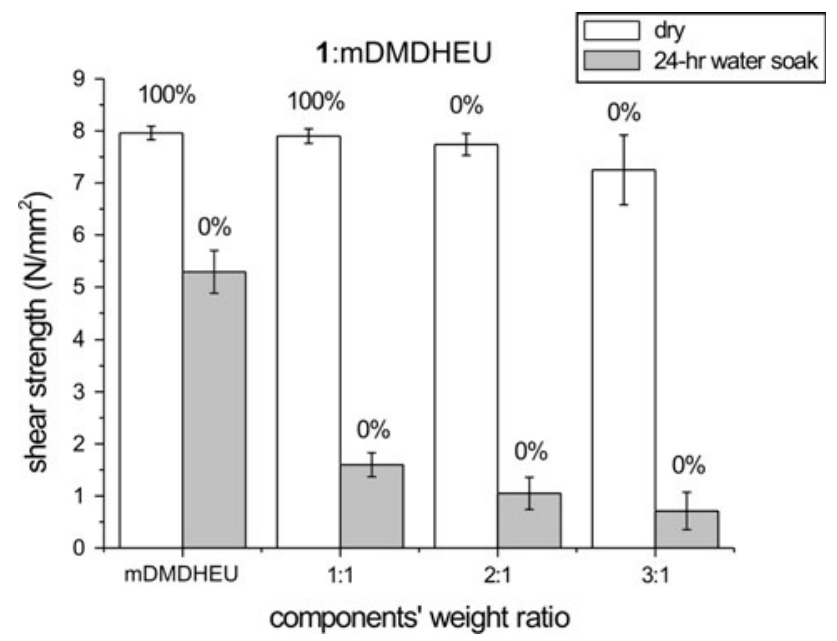

Fig. 4 Shear strengths of the bondlines of polyglycerol 1 -modified DMDHEU adhesive system

Abb. 4 Scherfestigkeit der Klebfugen des Klebstoffsystems aus Polyglycerin 1 mitmodifiziertem DMDHEU

appropriate for industrial conditions and easy to achieve due to low reactivity of the system at ambient conditions. Activation energies calculated for the neat DMDHEU resins and 2:1-formulations showed that in each case addition of polyglycerol resulted in an increased $E_{a}$ of the system (Table 3).

\subsection{Shear strength of the joints}

The results of shear strength tests for the systems containing polyglycerol $\mathbf{1}$ are shown in Figs. 4 and 5. The

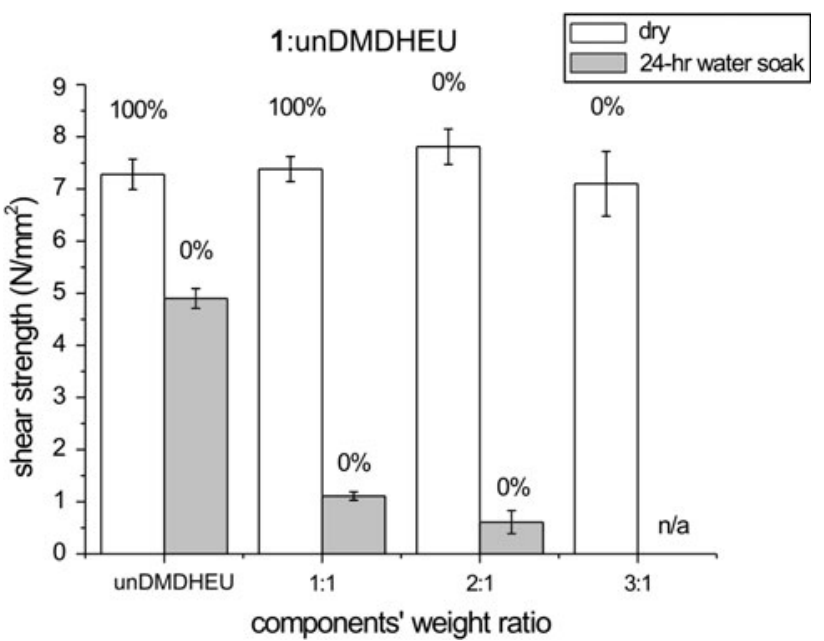

Fig. 5 Shear strengths of the bondlines of polyglycerol 1-unmodified DMDHEU adhesive system

Abb. 5 Scherfestigkeit der Klebfugen des Klebstoffsystems aus Polyglycerin 1 mit nicht modifiziertem DMDHEU

presented data indicate that dry shear strengths for the mDMDHEU-1 were comparable to that for neat mDMDHEU $(8.0 \pm 0.13 \mathrm{MPa})$. Up to $1: 2$ ratio the differences were insignificant, while for 1:3 ratio a significant decrease in strength $(7.2 \pm 0.67 \mathrm{MPa})$ was observed. For the unDMDHEU-1 system the obtained strengths were statistically insignificant and remained at neat unDMDHEU reference level $(7.3 \pm 0.30 \mathrm{MPa})$. However, $0 \%$ wood failure was observed for the 2:1- and 3:1-series containing polyglycerol 1. The bond lines of neat unDHDHEU exhibited $100 \%$ wood failure. 


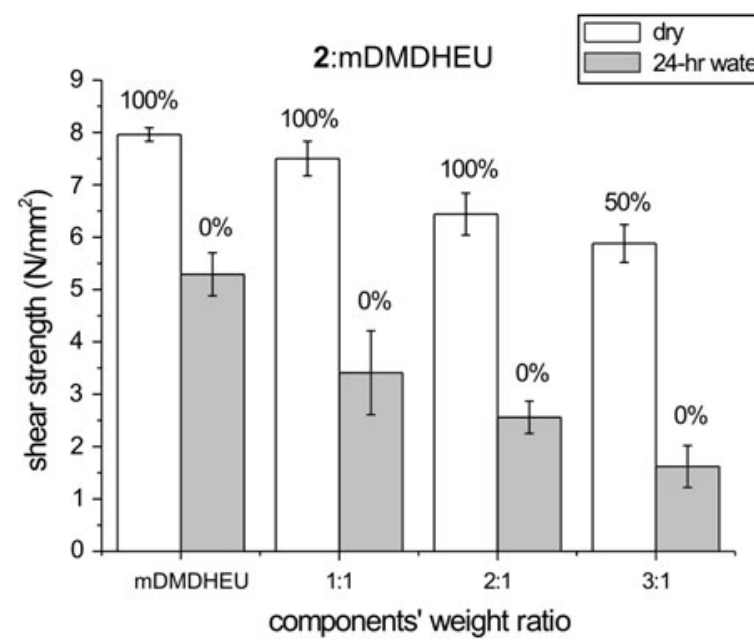

Fig. 6 Shear strengths of the bondlines of polyglycerol 2-modified DMDHEU adhesive system

Abb. 6 Scherfestigkeit der Klebfugen des Klebstoffsystems aus Polyglycerin 2 mit modifiziertem DMDHEU

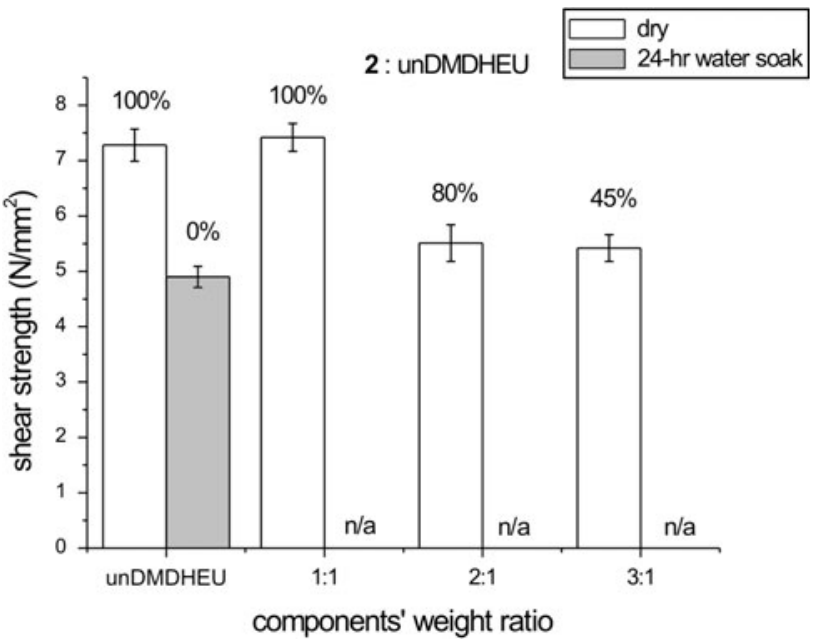

Fig. 7 Shear strengths of the bondlines of polyglycerol 2-unmodified DMDHEU adhesive system

Abb. 7 Scherfestigkeit der Klebfugen des Klebstoffsystems aus Polyglycerin 2 mit nicht modifiziertem DMDHEU

The formulations bearing polyglycerol 2 (Figs. 6, 7) exhibited somehow different performance. The strengths of the systems containing 1:1 components' ratio were comparable to those of the reference series. Increasing the content of polyglycerol resulted for both mDMDHEU and unDMDHEU systems in a reduction in shear strength that was proportional to the content of polyglycerol 2 and reached $5.9 \pm 0.36$ and $5.4 \pm 0.24 \mathrm{MPa}$ for mDMDHEU and unDMDHEU, respectively.

The phenomena are not surprising since polyglycerols may alter mechanical properties of the polymer. As reported by Parzuchowski et al. (2007) concentration of hyperbranched polyglycerol in the cured epoxy resin higher than $20 \%$ resulted in a significant plasticization of the polymer. Similar phenomena were observed by Essawy et al. (2009) for UF resins and by Dodiuk et al. (2004) for polyurethanes. It is rationale that polyglycerols added at levels above $50 \mathrm{wt} \%$ plasticized the cured polymers, since glass transition temperatures of $\mathbf{1}$ and $\mathbf{2}$ are -35.48 and $-29.14{ }^{\circ} \mathrm{C}$, respectively.

In contrary to polyglycerol 1, wood failure rates for 2:1and 3:1-series containing polyglycerol 2 (Figs. 6 and 7) ranged between 45 and $80 \%$. However, it is worth noting that wood substrate strength was below $6.0 \mathrm{MPa}$ (2-mDMDHEU 3:1 and 2-unDMDHEU 2:1, 3:1) which was lower than typically observed, as high wood failure rate was apparently caused by the variations in density or anatomic cross-section of the specimens subjected to testing.

Bondlines of neat DMDHEU resins exhibited moderate performance after $24 \mathrm{~h}$ water soaking: 5.29 and $4.90 \mathrm{MPa}$ for mDMDHEU and unDMDHEU, respectively. In addition, no wood failure was observed for the wet series. Moreover, additions of polyglycerols resulted in reduction of bondline shear strengths. The nadir was observed for the mixtures of polyglycerol 2 with unDMDHEU where $100 \%$ specimens delaminated during soaking.

The presented results confirmed the initial assumption that blending of synthetic resin with environmentally benign raw materials like hyperbranched polyglycerols was plausible and gave way to increase the rate of utilization of renewable resources (glycerol and its derivatives) in adhesive technology. It was shown that the bond lines containing $25 \mathrm{wt} \%$ of the synthetic petroleum-derived component (3:1 components' ratio) exhibited shear strength comparable to that of neat DMDHEU which proved retaining mechanical properties and load bearing capability in dry environment.

Comparison of the series containing fully aliphatic polyglycerol 1 with TMP core or polyglycerol $\mathbf{2}$ with aromatic core provided no evidence for the influence of core structure on the performance of the adhesive joints. The results remain in accordance with what was reported by Voit (2003) that not a core, but the end groups had a dominant effect on the properties of a hyperbranched polymer.

The presented results showed that DMDHEU-hyperbranched polyglycerols with terminal hydroxyl functionality systems are thermosets and it is proposed that the described systems might potentially be applicable in wood bonding, since joint strength made in solid wood exceeded that of the substrate.

\section{Conclusion}

The presented results clearly showed that development of thermosetting systems based on DMDHEU and 
hyperbranched polyglycerols was possible and the resultant shear strengths of the bond lines were higher than those of wood. A general outcome of those studies is that substitution of DMDHEU with glycerol-derived polyglycerols was possible, which potentially gives way for extending the area of application of that class of polymers to the field of adhesives.

Acknowledgments The authors would like to greatly thank Omnova Solutions Inc. and BASF Chemicals for kind donation of the DMDHEU resins.

Open Access This article is distributed under the terms of the Creative Commons Attribution License which permits any use, distribution, and reproduction in any medium, provided the original author(s) and the source are credited.

\section{References}

Alhanash A, Kozhevnikova FE, Kozhevnikov IV (2008) Hydrogenolysis of glycerol to propanediol over $\mathrm{Ru}$ : polyoxometalate bifunctional catalyst. Catal Lett 120:307-311

Anastas PT, Warner JC (1998) Green chemistry: theory and practice. Oxford University Press, New York

Ballerini A, Despres A, Pizzi A (2005) Non-toxic, zero emission tannin-glyoxal adhesives for wood panels. Holz Roh Werkst 63:477-478

Behr A, Eilting J, Irawadi K, Leschinski J, Lindner F (2008) Improved utilization of renewable resources: new important derivatives of glycerol. Green Chem 10:13-30

Bournay L, Casanave D, Delfort B, Hillion G, Chodorge JA (2005) New heterogeneous process for biodiesel production: a way to improve the quality and the value of the crude glycerin produced by biodiesel plants. Catal Today 106:190-192

Çetin NZ, Özman NI (2002) Use of organosolv lignin in phenolformaldehyde resins for particleboard production: II. Particleboard production and properties. Int J Adhes Adhes 22:481-486

Dieste A, Krause A, Bollmus S, Militz H (2009) Gluing ability of plywood produced with DMDHEU-modified veneers of Fagus sp., Betula sp., and Picea sp. Int J Adhes Adhes 29:206-209

Dodiuk H, Gold Z, Kenig S (2004) Tailoring new architectures for polyurethanes using dendritic and hyper-branched polymers and their adhesion behavior. Part 1. J Adhes Sci Technol 18:301-311

El Mansouri HR, Pizzi A (2006) Urea-formaldehyde-propionaldehyde physical gelation resins for improved swelling in water. J Appl Polym Sci 102:5131-5136

El Mansouri N-E, Pizzi A, Salvadó J (2007) Lignin-based wood panel adhesives without formaldehyde. Holz Roh Werkst 65:65-70

EN 205 (2005) Test methods for wood adhesives for non structural applications-Determination of tensile strength of lap joints

Essawy AH, Moustafa A-AB, Elsayed NH (2009) Improving the performance of urea-formaldehyde wood adhesive system using dendritic poly(amidoamine)s and their corresponding half generations. J Appl Polym Sci 114:1348-1355

Fradét A, Tessier M (2006) Average degrees of polymerization and molar masses of branched and hyperbranched condensation polymers: recursive probability approach. Macromolecules 39:6238-6247

Galina H, Krawczyk M (2007) A simple model of hyperbranched polymerisation involving $\mathrm{AB} 2$ and $\mathrm{B} f$ core monomers and methods of narrowing the molecular size distribution. Polym Bull 58:83-91
García R, Pizzi A (1998) Polycondensation and autocondensation networks in polyflavonoid tannins, Part 1: final networks. J Appl Polym Sci 70:1083-1091

IARC (2004) Press Release No. 153, IARC classified formaldehyde as carcinogenic to humans. http://www.iarc.fr/en/media-centre/ $\mathrm{pr} / 2004 / \mathrm{pr} 153 . \mathrm{html}$

Ibrahim NA, Allam AM, El-Hossamy MB (2008) Options for enhancing performance properties of easy-care finished cellulose/wool blended fabrics. Polym Plast Technol Eng 47:281-292

Kim SC, Kim YH, Lee H, Yoon DY, Song BK (2007) Lipasecatalyzed synthesis of glycerol carbonate from renewable glycerol and dimethyl carbonate through transesterification. J Mol Catal B Enzym 49:75-78

Krause A, Jones D, van der Zee M, Militz H (2003) Interlace treatment-wood modification with N-methylol compounds. In: Proceedings of 1st european conference on wood modification. Ghent, Belgium pp 317-327

Li K, Geng X, Simonsen J, Karchesy J (2004) Novel wood adhesives from condensed tannins and polyethylenimine. Int $\mathrm{J}$ Adhes Adhes 24:327-333

Liu Y, Li K (2007) Development and characterization of adhesives from soy protein for bonding wood. Int J Adhes Adhes 27:59-67

Mamiński M, Król M, Grabowska M, Głuszyński P (2011a) Simple urea-glutaraldehyde mix used as a formaldehyde-free adhesive: effect of blending with nano- $\mathrm{Al}_{2} \mathrm{O}_{3}$. Eur J Wood Prod 69:505507

Mamiński M, Parzuchowski P, Trojanowska A, Dziewulski Sz (2011b) Fast-curing polyurethane adhesives derived from environmentally friendly hyperbranched polyglycerols - the effect of macromonomer structure. Biomass Bioenergy 35:4461-4468

Mamiński M, Czarzasta M, Parzuchowski P (2011c) Wood adhesives derived from hyperbranched polyglycerol cross-linked with hexamethoxymethyl melamines. Int J Adhes Adhes 31:704-707

Melero JA, Vincente G, Paniagua M, Morales G, Muñoz P (2012) Etherification of biodiesel-derived glycerol with ethanol for fuel formulation over sulfonic modified catalysts. Bioresour Technol 103:142-151

Militz H (1993) Treatment of timber with water soluble dimethylol resins to improve their dimensional stability and durability. Wood Sci Technol 27:347-355

Papanikolau S, Muniglia L, Chevalot G, Aggelis G, Marc I (2002) Yarrowia lipolytica as a potential producer of citric acid from raw glycerol. J Appl Microbiol 92:737-744

Parzuchowski PG, Kiźlińska M, Rokicki G (2007) New hyperbranched polyether containing cyclic carbonate groups as a toughening agent for epoxy resin. Polymer 48:1857-1865

Ramadhas AS, Jayaraj S, Muraleedharan C (2005) Biodiesel production from high FFA rubber seed oil. Fuel 8:335-340

Rokicki G, Rakoczy P, Parzuchowski P, Sobiecki M (2005) Hyperbranched aliphatic polyethers obtained from environmentally benign monomer: glycerol carbonate. Green Chem 7:529539

Sánchez EA, D’Angelo MA, Comelli RA (2010) Hydrogen production from glycerol on $\mathrm{Ni} / \mathrm{Al} 2 \mathrm{O} 3$ catalyst. Int J Hydrogen Energy 35:5902-5907

Schaffert S, Krause A, Militz H (2005) Upscaling and process development for wood modification with $\mathrm{N}$-methylol compounds using superheated steam. In: Proceedings of 2nd European conference on wood modification. Göttingen, Germany, pp 161-168

Sudiyanni Y, Imamura Y, Takahashi M (1996) Weathering effects on several properties of chemically modified wood. Wood Res 83:55-58

United States Application (2011) US20110198028, Dynea Oy, Finland

Voit BI (2003) Hyperbranched polymers: a chance and a challenge. CR Chimie 6:821-832 
Wang S, Pizzi A (1997) Succinaldehyde induced water resistance improvements of UF wood adhesives. Holz Roh Werkst 55:9-12

Wepner F, Krause A, Militz H (2006) Weathering resistance of Nmethylol-treated plywood panels. In: Proceedings of 2nd international symposium on veneer processing and products. Vancouver, Canada pp 305-314

SDBSWeb: http://riodb01.ibase.aist.go.jp/sdbs/ (National Institute of Advanced Industrial Science and Technology)
Yang H, Yang CQ, He Q (2009) The bonding of a hydroxy-functional organophosphorus oligomer to nylon fabric using the formaldehyde derivatives of urea and melamine as the bonding agents. Polym Degrad Stab 94:1023-1031

Zhou CH, Beltramini JN, Fan YX, Lu GQ (2008) Chemoselective catalytic conversion of glycerol as a biorenewable source to valuable commodity chemicals. Chem Soc Rev 37:527-549 